INTER NATIONAL MONETARY FUND

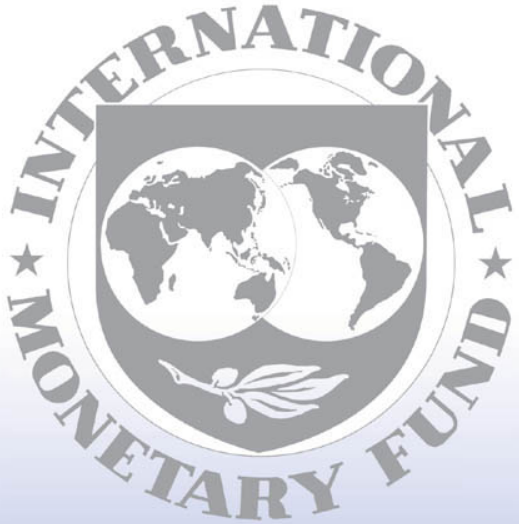

Staff

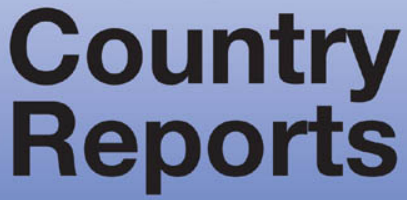




\section{Spain: Financial Sector Assessment Program-Detailed Assessment of the CPSS Core Principles for Systemically Important Payment Systems}

This Detailed Assessment of the CPSS Core Principles for Systemically Important Payment Systems for Spain was prepared by a staff team of the International Monetary Fund as background documentation for the Financial Sector Assessment Program with the member country. It is based on the information available at the time it was completed in May 2006. The views expressed in this document are those of the staff team and do not necessarily reflect the views of the government of Spain or the Executive Board of the IMF.

The policy of publication of staff reports and other documents by the IMF allows for the deletion of market-sensitive information.

To assist the IMF in evaluating the publication policy, reader comments are invited and may be sent by e-mail to publicationpolicy@imf.org.

Copies of this report are available to the public from

International Monetary Fund $\bullet$ Publication Services

700 19th Street, N.W. • Washington, D.C. 20431

Telephone: (202) 6237430 • Telefax: (202) 6237201

E-mail: publications@imf.org・Internet: http://www.imf.org

Price: $\$ 15.00$ a copy

International Monetary Fund

Washington, D.C. 
This page intentionally left blank 
FinANCIAL SECTOR ASSESSMENT PROGRAM SPAIN

\section{Detailed ASSESSMent OF OBSERVANCE OF THE CPSS CORE PRINCIPLES FOR SYSTEMICALLY IMPORTANT PAYMENT SYSTEMS \\ MAY 2006}


Contents

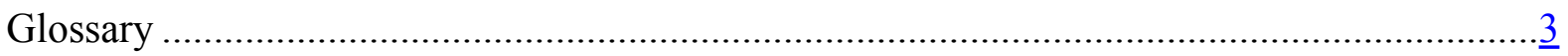

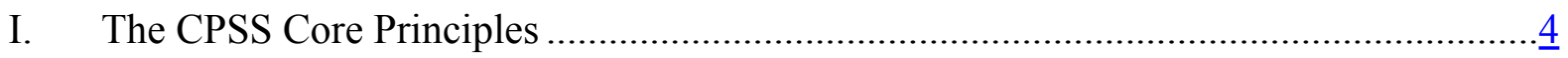

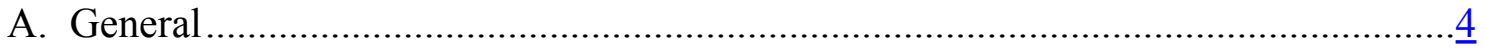

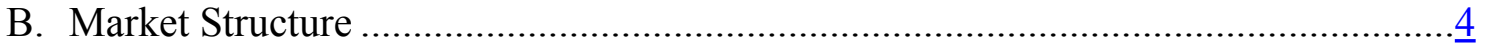

C. Payment Systems Infrastructure ..............................................................

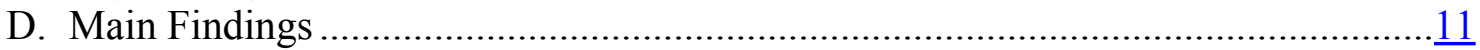

Tables

1. Indicators of Use of Various Cashless Payment Instruments_-Volume of Transactions ... $\underline{5}$

2. Indicators of Use of Various Cashless Payment Instruments - Value of Transactions ....... $\underline{6}$

3. SLBE: Transactions and Participants...................................................................

4. Practice-by-Practice Assessment of Observance of CPSS Core Principles for SIPS and Central Bank Responsibilities in Applying the CPs - The SLBE ..........13

4. Summary Observance of CPSS Core Principles and Bank Responsibilities

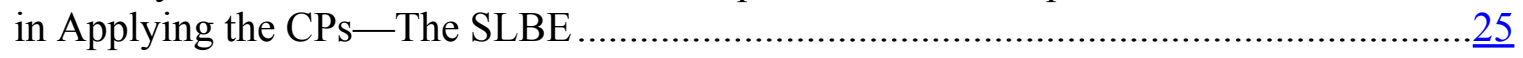

5. Recommended Action Plan to Improve Observance of CPSS Core Principles and Central Bank Responsibilities in Applying the CPs-The SLBE .$\underline{25}$ 


\section{GLOSSARY}

\begin{tabular}{|c|c|}
\hline ATM & automatic teller machine \\
\hline $\mathrm{BE}$ & Banco de España \\
\hline $\mathrm{CCBM}$ & Corresponding Central Bank Model \\
\hline $\mathrm{CCP}$ & Central counterparty \\
\hline CECA & Confederación Española de Cajas de Ahorro \\
\hline CEMLA & Centro de Estudios Monetarios Latinoamericanos \\
\hline CNMV & Comisión Nacional del Mercado de Valores \\
\hline $\mathrm{CP}$ & Core Principle \\
\hline CPSIPS & Core Principles for Systemically Important Payment System \\
\hline CPSS & Committee on Payment and Settlement Systems \\
\hline ECB & European Central Bank \\
\hline ESCB & European System of Central Banks \\
\hline $\mathrm{EU}$ & European Union \\
\hline FIFO & First In First Out \\
\hline IAC & International Advisory Committee \\
\hline IBERCLEAR & $\begin{array}{l}\text { Sociedad de Gestión de los Sistemas de Registro, Compensación y } \\
\text { Liquidación de Valores, S.A. }\end{array}$ \\
\hline IMF & International Monetary Fund \\
\hline PIPS & Prominent Important Payment System \\
\hline POS & Point of sale \\
\hline RTGS & Real-time gross settlement system \\
\hline SEMP & Sociedad Española de Medios de Pago \\
\hline SEPI & Servicio Español de Pagos Interbancarios \\
\hline SESP & Sociedad Española de Sistemas de Pago, S.A. \\
\hline SIPS & Systemically Important Payment System \\
\hline SLBE & Servicio de Liquidación del Banco de España \\
\hline SNCE & $\begin{array}{l}\text { Sistema Nacional de Compensación Electrónica (National Electronic Clearing } \\
\text { House) }\end{array}$ \\
\hline SPI & Servicio de Pagos Interbancarios \\
\hline STMD & Servicio Telefónico del Mercado de Dinero \\
\hline STP & straight-through processing \\
\hline $\mathrm{T}$ & trade date \\
\hline TARGET & Trans-European Automated Real-Time Gross Settlement Express Transfer \\
\hline WHI & Western Hemisphere Payments and Securities Initiative \\
\hline
\end{tabular}




\section{The CPSS Core Principles}

\section{A. General}

1. The assessment of the Systemically Important Payment System (SIPS) in Spain against the Committee on Payment and Settlement Systems (CPSS) Core Principles covered one system: Servicio de Liquidación del Banco de España-SLBE (a Real-Time Gross Settlement System-RTGS). ${ }^{1}$ It did not assess Spain's link to the Trans-European Automated Real-Time Gross Settlement Express Transfer system (TARGET). ${ }^{2}$ The assessment was undertaken by Marylin Choy (Central Bank of Peru) as part of the Financial Sector Assessment Program (FSAP) in June-July 2005.

2. The methodology for the assessment was derived from the Guidance Note for Assessing Observance of Core Principles for Systemically Important Payment Systems (CPSIPS) of the IMF and the World Bank of August 2001.

3. The assessment involved discussions with members of the staff of the Banco de España $(\mathrm{BE})$ and meetings with commercial banks. Counterparties met during the assessment were very cooperative and provided all the necessary information.

4. The assessment benefited from a self assessment by the BE and the assessment of the Euro Large-Value Payment System against the core principles published by the European Central Bank. It was based also on relevant laws and regulations of the $\mathrm{BE}$ and on information available on the website of the BE.

\section{B. Market Structure}

5. At end-2004, the financial sector included 346 credit institutions, of which 136 were commercial banks ( 75 national and 61 foreign), 47 saving banks (cajas), 83 credit cooperatives, 79 specialized credit institutions, and the state-owned Instituto de Crédito Oficial (ICO) ${ }^{3}$

\section{Cashless payment instruments}

6. Direct debits for recurrent payments such as utilities and other services, are the most important cashless means of payment in number of transactions. As average payment is low, they are less important relative to the total value of payments. The payment order is issued by

\footnotetext{
${ }^{1}$ This assessment was carried out by Marilyn Choy (Manager, Technical Affairs, Central Bank of Peru). The assessment took place from June 22 to July 1, 2005.

${ }^{2}$ The overall assessment of TARGET (Trans-European Automated Real-Time Gross Settlement Express Transfer) was part of the CPSS assessment for the euro-area payment system conducted in November 2001 (see IMF Country Report No. 01/195); the assessment of transparency of monetary policy for the euro area was completed at the same time.

${ }^{3}$ Source: Statistical Bulletin of Banco de España 2004 (September 2005).
} 
the creditor, with prior authorization from the debtor to charge his account. A payment invoice is sent to the debtor who can reject the payment in case it is incorrect.

7. Debit cards allow the owner to make payments with direct charge to his account through an ATM or POS. The receiver's account is credited the next day. There are around 1,400 debit and credit cards per 1,000 people. There are three nets of suppliers: Sociedad Española de Medios de Pago (SEMP), Sistema 4B, and Euro6000 managed by the Confederación Española de Cajas de Ahorro (CECA). Payments by debit cards, and other paperless payments in general, are also increasing in number.

Table 1. Indicators of Use of Various Cashless Payment Instruments-Volume of Transactions

(In millions)

\begin{tabular}{lrrrrr}
\hline & \multicolumn{5}{c}{ Year ended } \\
\cline { 2 - 6 } & 2000 & 2001 & 2002 & 2003 & 2004 \\
\hline Checks issued & 197.4 & 166.7 & 168.0 & 177.0 & 204.5 \\
Payments by debit cards & 286.6 & 340.1 & 612.4 & 630.9 & 692.8 \\
Payments by credit cards & 221.8 & 259.0 & 400.8 & 465.3 & 578.1 \\
Paper-based credit transfers & 57.5 & 71.0 & 83.3 & 151.7 & 90.8 \\
Paperless credit transfers 1/ & 280.6 & 283.2 & 326.3 & 470.4 & 633.2 \\
Direct debits & $1,175.9$ & $1,154.3$ & $1,192.2$ & $1,382.9$ & $2,118.0$ \\
E-money & 1.8 & 1.1 & 1.2 & 1.3 & 0.6 \\
Other & 129.8 & 114.6 & 91.3 & 94.4 & 129.8 \\
Total & $2,351.4$ & $2,390.0$ & $2,875.5$ & $3,373.9$ & $4,447.8$ \\
\hline
\end{tabular}

Source: Banco de España

1/ Excludes interbank large value transfers.

8. Table 1 indicates that:

- Checks are still important in value but their importance is declining relative to the use of electronic means of payments.

- Electronic transfers from current and savings accounts to pay salaries, subsidies and pensions constitute the most important means of payment in value.

- Although in general not of extended use, there are other means of payments such as prepaid cards, commercial cards, post office payments, and e-money. 
Table 2. Indicators of Use of Various Cashless Payment Instruments - Value of Transactions (In billions of euros)

\begin{tabular}{lrrrrr}
\hline & \multicolumn{5}{c}{ Year ended } \\
\cline { 2 - 6 } Checks issued & 2000 & 2001 & 2002 & 2003 & 2004 \\
\cline { 2 - 6 } Payments by debit cards & 749.5 & 735.4 & 735.8 & $1,053.7$ & 902.4 \\
Payments by credit cards & 11.3 & 13.9 & 25.1 & 27.5 & 30.6 \\
Paper-based credit transfers & 13.6 & 15.5 & 23.9 & 28.4 & 35.4 \\
Paperless credit transfers 1/ & 188.4 & 273.4 & 313.2 & 626.3 & $1,056.9$ \\
Direct debits & 776.7 & $1,004.2$ & $1,249.8$ & $1,910.3$ & $3,906.0$ \\
E-money & 368.4 & 310.7 & 438.2 & 459.9 & 770.6 \\
Other & 0.1 & 0.1 & 0.0 & 0.0 & 0.0 \\
Total & 254.3 & 245.8 & 219.1 & 599.3 & 425.7 \\
\hline
\end{tabular}

Source: Banco de España.

1/ Excludes interbank large value transfers

\section{Payment Systems Infrastructure}

\section{Legal framework}

9. Law 41/1999 of November 12, also known as the Settlement Finality Law, provides the general legal framework for the payment and securities settlement system. The law clearly states the irrevocability and finality of a payment order and recognizes the legal validity of clearing agreements. It also establishes the procedures and consequences of legal insolvency of a participant in a payment system, and covers the clearing agreements, the transfer orders and the collateral deposited in the system. The law also establishes expeditious proceedings for the execution of collateral in case of default. Insolvency proceedings do not have retroactive effects on payment orders and collateral that have been put through the payment system.

10. Law 24/1988, Law of the Securities Market, issued on July 28, 1988, and modified among others, by Law 37/1998 of November 16 and Law 44/2002 of November 22, govern the securities settlement systems.

11. Other legislation, such as Law 16/1989, Defense of Competition Law, of July 17 and modified by Law 52/1999 of December 28, and Law 26/1988, Discipline and Intervention of Credit Entities Law, apply to the payment systems in aspects related to competition and consumer protection.

12. Specific regulations and circulars issued by the BE govern the payments system. Access criteria, prices, operational timetable and calendar, and access to intraday credit, among other issues, are covered by these regulations. 
13. Law 13/1994, on Bank of Spain Autonomy, establishes that the BE must promote the well functioning and stability of the financial system and of the payment system, and entitles $\mathrm{BE}$ to regulate and operate clearing and settlement systems. The Law empowers the BE with the oversight function of the payment and settlement systems, and provides that it may gather information and documentation to evaluate the system's efficiency and reliability (Law 2/2004 of December 27). The BE can suspend the decisions adopted by the entity managing a payment system when it considers that those decisions are prejudicial to the payment system, and can take any necessary measures.

14. The National Securities Market Commission (Comisión Nacional del Mercado de Valores, CNMV), created by Law of the Securities Market, is in charge of the oversight of the securities settlement systems.

\section{Recent reform}

15. Spain used to have three payment systems: two for large value and one for small payments. The large value payment systems were: the Gross Settlement System of Spain (Servicio de Liquidación del Banco de España-SLBE) managed by the central bank, and the Interbank Payment System (Servicio Español de Pagos Interbancario-SEPI). The SEPI was a private clearing house for large value payments in euros, domestic and cross border, managed by the Servicio de Pagos Interbancarios (SPI). Small value payments were processed through the National Electronic Clearing System (Sistema Nacional de Compensación Electrónica-SNCE), managed by the BE.

16. A reform of the payment system was introduced in December 2004. The SPI was reorganized and legally transformed into a new private company called Sociedad Española de Sistemas de Pago, S.A. (SESP) and its functions as a large value payment system manager were eliminated (thus the SLBE is the only large value payment system). The SNCE is no longer managed by the central bank. The SESP is in charge of the management of the SNCE, and is overseen by the $\mathrm{BE}$ who approves the rules of the system.

17. The guiding principle was to establish separate systems for large and retail payments. All payments above $€ 50,000$ channeled through the SEPI are now processed by the SLBE and smaller value payments are made through the SNCE.

\section{Large-value payment system}

18. There is one large-value interbank payment system: the Servicio de Liquidación del Banco de España (SLBE). It is the only systemically important payment system, given the high individual value payments it handles and that it is used for the settlement of the transactions of all relevant systems, like the stock exchange and the low-value payment system.

19. The SLBE is a Real-Time Gross Settlement (RTGS) system owned, operated, and controlled by the BE. It is the Spanish component of the TARGET, and settles both domestic 
and cross-border operations. It was created in 1997 with the transformation of the Servicio Telefónico del Mercado de Dinero (STMD).

\section{Legal aspects}

20. The SLBE is one of the payment systems legally recognized by the Settlement Finality Law. Therefore, payment orders processed by this system are irrevocable and have finality, there is not retroactivity in case of insolvency ("zero hour") and the BE has rights over the collateral pledged in the system in case of default.

21. The BE regulates the SLBE through circulars, technical applications (Aplicaciones Técnicas), and communications. Circulars are published in the Official Gazette (Boletín Oficial del Estado) and at Banco de España's website.

22. The manual of the SLBE is contained in Circular 5/1990 and its modifications. This Circular includes the contract of acceptance of the rules and regulations of the system. The Manual addresses issues such as access conditions and criteria, fees, sanctions, operation timetable, procedures to access the intraday credit and for cross-border payments, among others. It also establishes that a foreign participant should present to the BE legal opinions obtained in its jurisdiction about its capacity to comply with its obligations under system rules.

23. Circular 3/2000, in accordance with Law 41/1999, establishes that payment orders communicated cannot be modified or cancelled by the participant. Once the participant's account is debited in real time, the payment order is irrevocable. The legal framework therefore is sound and contains clear rules and procedures both for normal operations and for the case of insolvency of a participant.

\section{Participants}

24. The SLBE is an open system with participation of credit institutions established in any European Euro Area country, and investment service institutions that are subject to prudential supervision. Treasury departments of central and regional governments and clearing houses such as the stock exchanges and IBERCLEAR, that are subject to oversight, also participate in this system.

25. There are 184 direct participants ( 33 branches of foreign institutions) and 36 indirect participants in the system. Direct participants have to open a centralized account on the books of Banco de España (RTGS account) for the settlement of transactions, and can act both on their own behalf and on behalf of their customers.

26. Direct participants must be registered at the BE, must have adequate financial strength and must meet other technical and operational criteria. These requirements are included in the manual of the SLBE. 
Table 3. SLBE: Transactions and Participants

\begin{tabular}{lccc}
\hline Number of participants & $\begin{array}{c}\text { Daily value of } \\
\text { transactions } \\
\text { (In millions of euros) }\end{array}$ & $\begin{array}{c}\text { Average value per } \\
\text { transaction settled } \\
\text { (In millions of euros) }\end{array}$ & $\begin{array}{c}\text { Daily volume of } \\
\text { instructions }\end{array}$ \\
\hline $\begin{array}{l}184 \text { direct } \\
36 \text { indirect }\end{array}$ & 305,000 & 17 & 18,250 \\
\hline
\end{tabular}

Source: Banco de España.

\section{Operational proceedings}

27. The SLBE settles domestic and cross border transfers, secondary market operations, multilateral clearing systems and monetary operations. It also matches interbank operations and transactions with public debt securities. The main operations in volume are those related to public debt transactions, followed by cross-border transfers. National transfers and money market operations are next in importance followed by the clearing house settlements.

28. Payment orders are processed one by one in real time, debiting and crediting the accounts in the central bank, provided that sufficient funds or collateral are available in the debit account. In case of insufficient funds, orders go to a queue which has a bypass FIFO management. Priority of orders is managed by the participants. Once funds are received, the first transaction in the queue is settled unless its value exceeds the funds received. In this case, the system will search for a transaction in the queue that can be settled.

29. Intraday credit is available either via repo operations or pledge, with no charge. Specific assets and securities with a minimum rating are accepted as collateral for the intraday facility, according to the criteria of the Eurosystem. Securities are blocked in IBERCLEAR or other depositaries in favor of the BE. The central bank can suspend the intraday facility under circumstances of systemic risk (e.g., insolvency of a participant).

30. The SLBE has liquidity optimization mechanisms in case of gridlock. Bilateral netting is performed automatically during the session when the account does not have enough funds for a payment and before sending residual payment orders to the queue. Multilateral netting is executed by the manager of the system in case it is necessary for example, to settle all the pending operations at the end of the session.

31. A settlement timetable for the different multilateral netting systems allows participants to manage liquidity with a view to avoiding failures in the settlement of ancillary systems.

32. Participant institutions also have the possibility to use a new "liquidity reservation facility," to assure funds for specific payments. This facility allows participants voluntarily to put aside funds to assure availability for specific payments. It is recommended that the BE monitor the use of this facility to avoid possible discrimination against certain payments that 
may have to wait until the end of the day to be settled and to make sure that it does not unduly prevent the central bank from debiting accounts during the day.

33. At the end of the day, orders not settled and still in the queue are cancelled. If a participant is not able to undo the intraday facility, this credit becomes overnight, using the standing facility of the Eurosystem.

34. The communication system is by SWIFT or through an "online" connection to a BE computer. All external communication lines are encrypted and have a security access system. Remote access is allowed to entities outside Spain. There is a backup site in an external center that allows recovery of the system in less than two hours. The BE has contingency plans for emergency situations that are tested regularly.

35. The SLBE operates from 7:00 to 18:00. Charges and fees in the SLBE are based on cost recovery. There is a monthly charge of $€ 500$ and a fee of $€ 0.50$ for domestic transfers.

36. The SLBE is a modern and efficient RTGS system. It is expected to be replaced by TARGET 2 when the latter is introduced in 2007.

\section{Retail payments system}

37. Retail payments are processed by the SNCE, created by Real Decreto 1369/1987. The SESP manages the system. It is recognized as a payment system falling under the Settlement Finality Law. Transactions are not exposed to any retroactive actions and settlement agents are protected in case of insolvency of one of the participants.

38. In 1990 the first ACH began to operate, clearing only checks. The SNCE has grown rapidly since 2001 and it is the only electronic clearing house for retail payment instruments, such as paper checks, traveler's checks, direct debits, credit transfers, bill of exchange, and gas checks. ${ }^{4}$ These instruments are operated by several clearing sub-systems, according to a governing law.

39. The SNCE falls under the classification of Prominent Important Payment System (PIPS) in the Eurosystem standard considering the market penetration criteria, the aggregate financial risks and the domino effect risk. It is not a Systemically Important Payment System due to the low value of the transactions (the daily average value of transactions is around $€ 6$ billion compared with $€ 305$ billion cleared the SLBE). The result of the multilateral clearing is low relative to participant liquidity.

40. Commercial banks, saving banks, and credit cooperatives can be members of the SNCE. There are two forms of participants: direct and indirect participants. A direct participant takes part in the exchange stage of the clearing and settlement process, acting on

\footnotetext{
${ }^{4}$ Gas checks are payment orders on a customer's current account for payments at gas stations.
} 
its own behalf or representing indirect participants. There are 25 direct participants and 202 indirect participants.

41. The SNCE is based on the bilateral exchange of information by electronic means using private virtual network and STP processes. There is a truncation agreement among the participants so that 99.5 percent of the clearing is done without physical exchange of documents.

42. Each pair of institutions report their bilateral net balances to the BE. If no discrepancies are found in the bilateral exchange of information in each subsystem, a multilateral net position is calculated. The settlement takes place through the SLBE on the accounts that the participants hold at the BE by first debiting short participant's accounts before crediting the long ones. Payments over $€ 50,000$ are transmitted to the $\mathrm{BE}$ to be settled one by one.

43. Each subsystem has its own timetable for communications. In general, the cycle begins in $\mathrm{T}$, followed by bilateral exchange of information, and settlement takes place in $\mathrm{T}+1$. Settlement is considered final. There is no cost for participating in the SNCE except for connectivity and a software license fee.

\section{Main Findings}

44. The BE is an important player in the payment system and has a well established and cooperative relationship with the financial sector. Its role and responsibilities are clearly defined in the law, including the oversight function.

45. The legal framework is sound. The Settlement Finality Law is fully enforceable. Irrevocability and finality are clearly defined in the law and in the regulations of the system, and they are also ensured even in the event of insolvency of a participant. The relevant rules and regulations of the SLBE system are contained in a number of documents issued and modified by the BE. Although rules and regulations address all the relevant aspects of the system, they are contained in a number of circulars which are quite difficult to follow, so it is recommended that the $\mathrm{BE}$ consolidates its payment circulars to improve readability and transparency for participants. BE staff has indicated that efforts in this direction are in progress.

46. The infrastructure for clearing and settlement of payments is well developed, modern and functional. The SLBE has systems that offer protection against liquidity and credit risks, such as queuing mechanisms, intraday credit and bilateral and multilateral algorithms. The needs of the users are accounted for in the development of the payment infrastructure. The introduction of the liquidity reservation facility is an example of requirements fulfilled by the BE. However, the BE should monitor the use of this facility to avoid possible discrimination against certain payments that may have to wait until the end of the day to be settled and to make sure that it does not unduly prevent the central bank from debiting accounts during the day. 
47. There are contingency plans to assure continuity in the SLBE. However, the procedures in the manual of the SLBE should give clearer guidance on the expected behavior of participants in case of emergency situations. For instance, the procedures in case of failure of the platform of a participant or the SLBE should be clearly established. Although the BE conducts regular testing of the contingency plan with the cooperation of system participants, it is recommended to establish that participants have in place clear internal policies and procedures, and carry out operating audits. A periodic review of the IT infrastructure by participants to avoid operational risks is recommended. The distance of the external backup center from the main site should also be evaluated to make sure that it is sufficient in case of events such as natural disasters or terrorism.

48. The BE complies with its oversight function to ensure the safety and efficiency of payment systems. Oversight is based on data analysis, the analysis of payment instruments and new developments and self-assessment under international standards, among other aspects. As a result of its oversight activities the BE produces statistics and reports. It is recommended that this material be disseminated and published periodically. 


\section{Table 4. Practice-by-Practice Assessment of Observance of CPSS Core Principles for SIPS and Central Bank Responsibilities in Applying the CPs-The SLBE}

\begin{tabular}{|c|c|}
\hline Principle 1. & The system should have a well-founded legal basis under all relevant jurisdictions. \\
\hline Description & 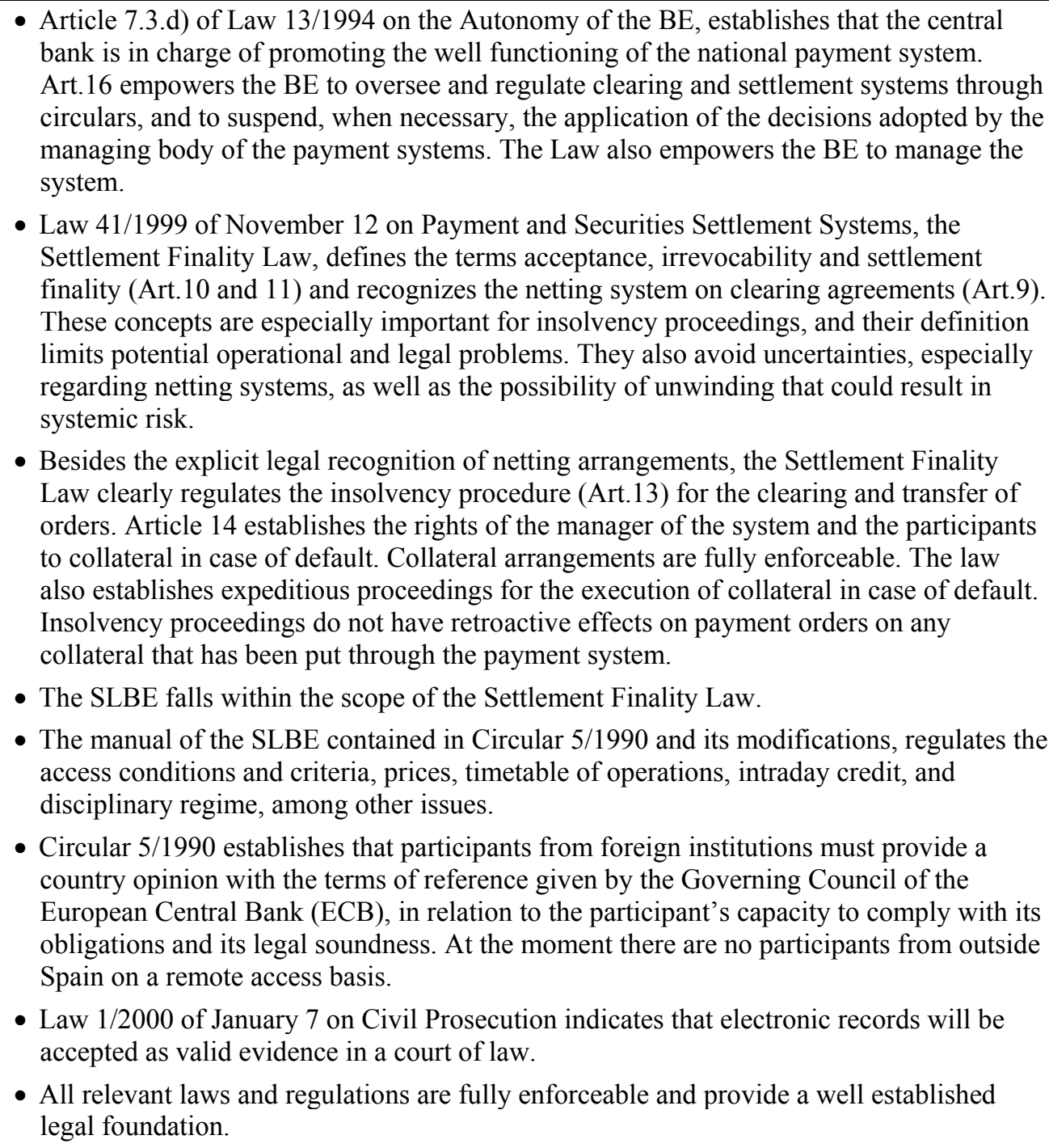 \\
\hline Assessment & Observed. \\
\hline Comments & \\
\hline Principle 2. & $\begin{array}{l}\text { The system's rules and procedures should enable participants to have a clear under- } \\
\text { standing of the system's impact on each of the financial risks they incur through } \\
\text { participation in it. }\end{array}$ \\
\hline Description & $\begin{array}{l}\text { - The SLBE operating rules and procedures are described in the manual of the SLBE and } \\
\text { comprise Circulars, Technical Applications and Communications of the BE. } \\
\text { - These regulations and communications explain the details of the system's design, its }\end{array}$ \\
\hline
\end{tabular}


timetable, intraday credit access, risk management procedures, the system's legal basis, and the rights and obligations of the parties.

- The procedure for sending and receiving payments and their final settlement is transparent. All participants are aware of the finality and irrevocability of their transactions, which are processed in real time, as long as the sender has enough funds or sufficient collateral. Therefore, participants do not face credit risk, as they are operating in a real time gross settlement system.

- The information on processing and settlement of payment orders and the rules for access to intraday credit granted by the system (as explained in Principle 3) is clear and allows participants to understand the liquidity risk management. Additional mechanisms of the system, such as the queue arrangement and the algorithms to solve gridlocks, are also explained in the rules and regulations that govern the SLBE.

- The degree of discretion is minimal for the $\mathrm{BE}$ and it is well explained in the regulation. For instance, the BE could modify intraday credit conditions owing to systemic liquidity needs or to the insolvency of a participant. In addition, the BE could adopt the required measures to ensure the adequate flow of operations, such as the use of the optimization mechanism for multilateral settlement.

- The regulations also include dispositions and procedures for handling special situations, such as the insolvency of a participant.

- The circulars are published in the Official Gazette (Boletín Oficial del Estado) and rules are available to all interested parties and are publicly disclosed on the BE website .

- All participants are provided with the relevant documents when they join the system.

- The rights and obligations of the participants, the operator, and the settlement institution are explained in the manual of the SLBE.

- Participants receive real-time information on the state of their accounts at the BE, and on any system-wide relevant information. The data provided by the SLBE includes information on the balance of the accounts, settled and queued orders, domestic payments blocked due to lack of funds in the sender's account, state of the clearing and settlement processes of the net multilateral systems and the, state of the cross-border payments, among others. All the real time information is complemented by virtual projections and forecasts of the account's balance taking into account the state of the queues. Each participant is also informed about the daily turnover and the final balance. This information is meant to give participants all the necessary elements to efficiently manage their liquidity, and to guarantee the orderly flow of payments in the system.

- The system manager regularly sends messages updating participants on problems that may have occurred in the SLBE. Information about the system and any other national component of TARGET is also available through the TARGET Information System (TIS).

- The BE works and coordinates with the Group of Users of the SLBE and the Working Group of Payment Systems (see Principle 10) on issues related to the system, including operational and liquidity risk management matters. These groups are also informed about failures or problems that could have occurred in the SLBE, so that they can analyze their impact and discuss measures to prevent such events from recurring. Participants are always informed in advance of any project or reform to be implemented by the BE.

- The provision of real time information on relevant aspects of the system and the coordination provided through the groups allow participants to be continuously informed and aware of the risk management of the SLBE, enhancing their overall understanding of the system.

- The understanding of the participating credit institutions is ensured through the mandatory infrastructure and functional tests they must complete before initiating operations as new participants in the SLBE. 


\begin{tabular}{|c|c|}
\hline & $\begin{array}{l}\text { - The BE carries out tests with the participation of the credit institutions before introducing } \\
\text { any change in the SLBE system. } \\
\text { - Participants must also participate in periodic tests of the system (see Principle 7). These } \\
\text { tests cover contingency planning and simulations of exceptional and extreme situations, } \\
\text { thus preparing users to deal with operational and business continuity failures. }\end{array}$ \\
\hline Assessment & Observed. \\
\hline Comments & $\begin{array}{l}\text { The relevant rules and regulations of the system are contained in a number of documents } \\
\text { issued and modified by the BE. Although those rules and regulations appear to address all } \\
\text { the relevant aspects of the system, they are contained in a number of circulars which are } \\
\text { quite difficult to follow. It is recommended that the organization of the circulars of the BE } \\
\text { are improved to enhance their readability and transparency. The mission has learned from } \\
\text { BE staff that efforts in this direction are in progress. }\end{array}$ \\
\hline Principle 3. & $\begin{array}{l}\text { The system should have clearly defined procedures for the management of credit risks } \\
\text { and liquidity risks, which specify the respective responsibilities of the system operator } \\
\text { and the participants and which provide appropriate incentives to manage and contain } \\
\text { those risks. }\end{array}$ \\
\hline Description & 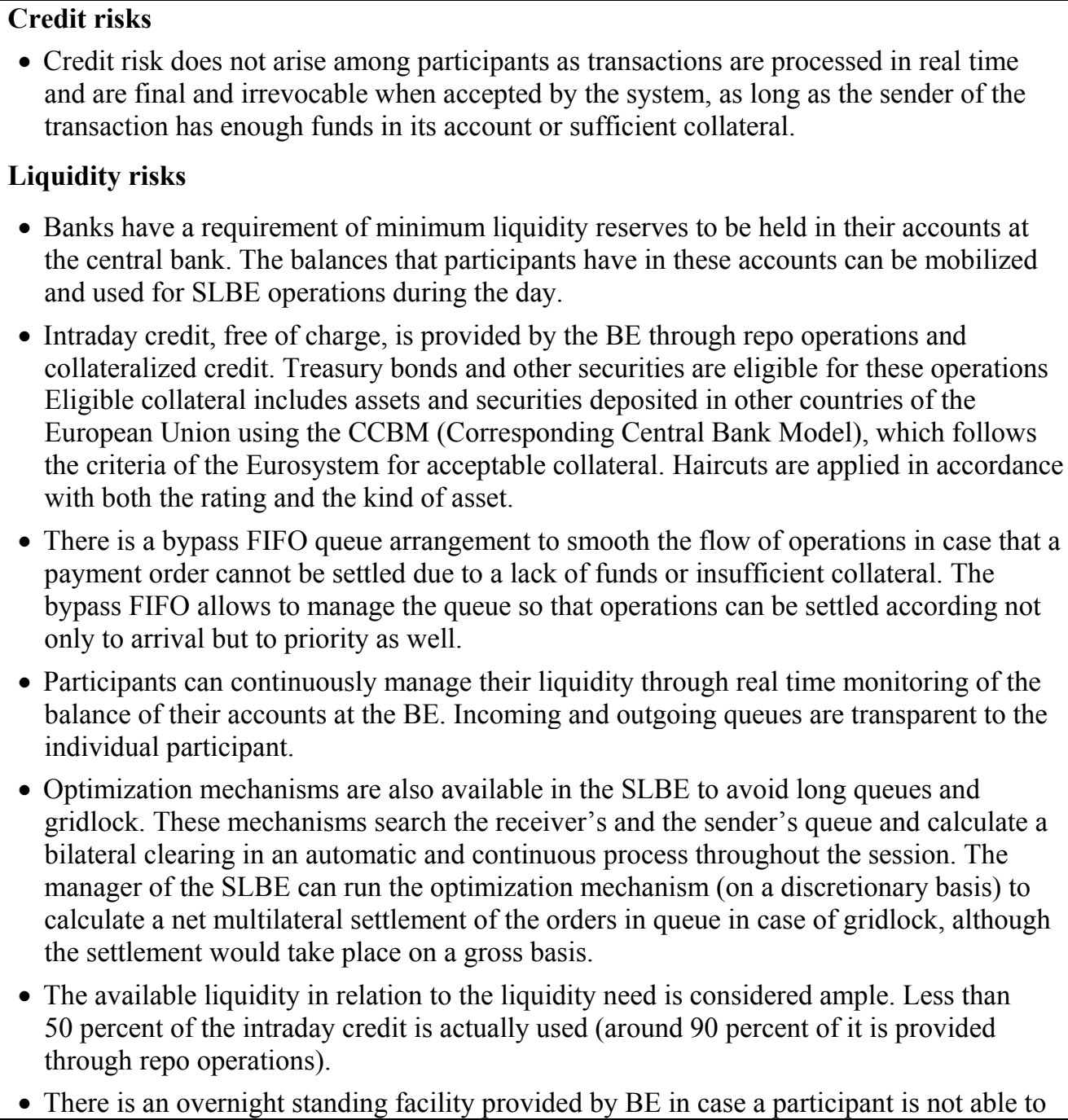 \\
\hline
\end{tabular}




\begin{tabular}{|c|c|}
\hline & $\begin{array}{l}\text { return the intraday credit. In this case, the intraday credit becomes overnight using the } \\
\text { same collateral, at a penalty interest rate. } \\
\text { - Since January } 2005 \text { a liquidity reservation system allows participants to reserve liquidity } \\
\text { in their accounts (on a discretionary basis) in amounts needed to ensure the settlement of } \\
\text { important payments. Participants can choose different criteria for the use of the reserved } \\
\text { liquidity: by participant, type of payments, or specific operations. } \\
\text { - The SLBE has a time schedule for the settlement of ancillary systems during the session, } \\
\text { which helps participants manage their liquidity. }\end{array}$ \\
\hline Assessment & Observed. \\
\hline Comments & $\begin{array}{l}\text { The liquidity reservation facility is very useful for participants to manage their liquidity. } \\
\text { However, the BE should monitor the use of this facility to avoid possible discrimination } \\
\text { against some payments that may have to wait until the end of the day to be settled and to } \\
\text { make sure that it does not unduly prevent the central bank from debiting accounts during the } \\
\text { day. }\end{array}$ \\
\hline Principle 4. & $\begin{array}{l}\text { The system should provide prompt final settlement on the day of value, preferably } \\
\text { during the day and at a minimum at the end of the day. }\end{array}$ \\
\hline Description & $\begin{array}{l}\text { - The rules of SLBE (Circular } 3 / 2000 \text { of May } 31 \text { ) define acceptance, irrevocability and } \\
\text { finality of the transactions, according to the Settlement Finality Law. } \\
\text { - The SLBE is a real time gross settlement system. Transactions are irrevocable from the } \\
\text { moment they are accepted by the system. They are final from the moment the account of } \\
\text { the institution involved is debited. } \\
\text { - RTGS transactions submitted to the system are "accepted for settlement" only when the } \\
\text { sender's account in the central bank has enough funds or intraday credit (fully } \\
\text { collateralized) is available. Transactions wait in a queue until funds are available (see } \\
\text { CP III). Payment orders cannot be revoked, cancelled or modified by the originator. Once } \\
\text { the payment has been settled it is irrevocable and final. } \\
\text { - Submission, validation, irrevocability and finality are clearly defined. } \\
\text { - The working hours of the SLBE ensure a final settlement on the day of value. }\end{array}$ \\
\hline Assessment & Observed. \\
\hline \multicolumn{2}{|l|}{ Comments } \\
\hline Principle 5. & $\begin{array}{l}\text { A system in which multilateral netting takes place should, at a minimum, be capable of } \\
\text { ensuring the timely completion of daily settlements in the event of an inability to settle } \\
\text { by the participant with the largest single settlement obligation. }\end{array}$ \\
\hline Description & RTGS system. \\
\hline Assessment & Not applicable. \\
\hline \multicolumn{2}{|l|}{ Comments } \\
\hline Principle 6. & $\begin{array}{l}\text { Assets used for settlement should preferably be a claim on the central bank; where } \\
\text { other assets are used, they should carry little or no credit risk and little or no liquidity } \\
\text { risk. }\end{array}$ \\
\hline
\end{tabular}




\begin{tabular}{|c|c|}
\hline Description & $\begin{array}{l}\text { - The system operates and settles in central bank money. Participants have a centralized } \\
\text { account ("cuenta única") or Treasury Accounts with the BE and the payments processed } \\
\text { by the SLBE are settled in these accounts. } \\
\text { - There is no credit risk or liquidity risk incurred by the participants with respect to the } \\
\text { settlement agent and with respect to the settlement asset. }\end{array}$ \\
\hline Assessment & Observed. \\
\hline Comments & \\
\hline Principle 7. & $\begin{array}{l}\text { The system should ensure a high degree of security and operational reliability and } \\
\text { should have contingency arrangements for timely completion of daily processing. }\end{array}$ \\
\hline & 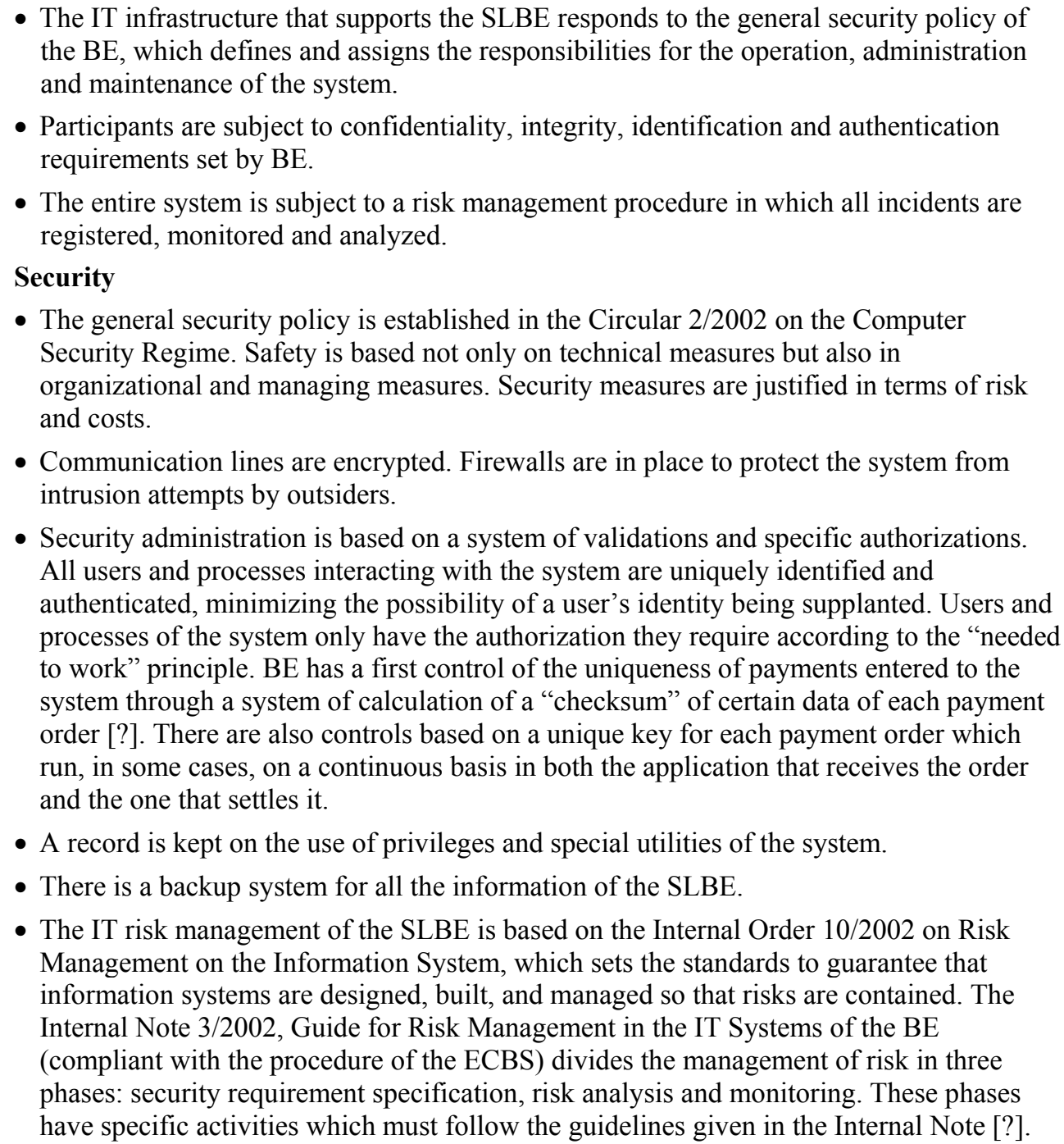 \\
\hline
\end{tabular}


- There is a detail of the security requirements for each system [?], including the SLBE, related to the definition and main values of availability of the system, integrity, authentication, confidentiality, access control, and auditing. Identification of the functions of the system, its components, limits and fields of responsibilities are executed in the first stage. The risk analysis is based on the identification of possible threats and vulnerable points of the system and the likelihood of their occurrence. There is also a questionnaire to evaluate the potential impact of identified risks and the measures to be taken regarding physical security and software security. Residual risks are identified, reported, and evaluated if they are within the acceptable limits set by the owner of the system. A record is kept of all incidents. Monitoring is carried out by the Internal and External Audit function.

\section{Operational reliability}

- All system components are duplicated. All communication lines have backups or are duplicated. There are also completely separate alternative communication routes. Wherever there is competition among different communication providers, the required service levels are established. All the participant institutions have alternative mechanisms of communication.

- The system can be recovered without loss of information. There are procedures to make back-up copies of all software and information related to the system. The back-up and recuperation processes are implemented at different levels depending on, both, the type of information to be recovered (data, programs, etc) and the incidence that caused the loss of information.

- The monthly indicator of availability of the system (measured as a percentage of the operational time over the scheduled time) was 100 between the months of January to August 2005, except for three months when the indicator was 99.7, 99.9 and 99.9.

- There are IT tools for monitoring the capacity and adjustment of the system. The BE staff reported that it is difficult to measure the maximum capacity of the system because the central computer is not exclusively dedicated to the SLBE and it performs other programs for the operations of the BE. The staff estimates that the computer has more than enough capacity dedicated to the SLBE to perform the actual volume of the operations. However, in case it was necessary, the IT department could stop the execution of other programs of lower priority, in order to augment the capacity available to SLBE. This mechanism adds flexibility to satisfy any extraordinary increase in the number of operations and at the same time avoid excess permanent idle capacity

- There are IT tools for monitoring capacity and adjustment of the system (Mainview, SMF/MICS and other self developed tools). These tools are designed to guarantee that the system can process, in a timely manner, the expected volume of payments and also to forecast changes in the current trend of activity.

- The system is audited by the internal Audit Department. Internal and External audits have been performed of several system components, such as SWIFT. 


\section{Business continuity}

- There is a contingency plan to assure business continuity in the SLBE. The plan includes a Crisis Consulting Board whose chairman is the chief of the IT Department.

- There is an external backup center for the IT infrastructure used by the SLBE, with the same levels of security and controls as the main center. The backup site and the main site depend on different telecommunication and facility suppliers (light, water, and energy). The entire infrastructure and the different elements of the system are duplicated. There are mechanisms for synchronized copying of data between both processing centers.

- In case of disruption in the main system it is possible to restore the SLBE to normal activity in the external backup center in less than two hours. The BE staff reported no need of using the external backup center so far.

- Up to date, only minor problems have occurred, and they were generally resolved in less than 30 minutes. According to available data, since January 2003, the system has suffered 17 incidents, none of them being a "disaster failure". Some of them only caused a delay in the answer time, but not an interruption in the service. The average time of the interruption in the message process has been 14,5 minutes and the longest incident lasted 59 minutes. None of these failures caused a modification of the original schedule of the system. No problems of liquidity or settlement of the ancillary systems have been reported.

- The IT Department undertakes regular tests before introducing any change in the system. These tests are performed in several stages. First, they are performed with the IT personnel in charge of the implementation of the changes. Second, they are performed with the participation of the Payment System Department. Lastly, they include the users of the system. Before moving to the next stage, the results of the tests are verified and certified.

- The IT Department undertakes regular testing (at least as frequently as quarterly) of the contingency plan with the cooperation of the system participants. The procedures that activate the back up site are documented and updated by the IT Department.

- There is personnel from the IT Department permanently monitoring the system. That is, not only during business hours, but also before opening and after closing.

- There is a user help center available to all participants. The IT Department has programmers on duty at all times. Programmers strive to solve reported problems in less than 15 minutes.

- There are service agreements with the suppliers (such as SWIFT), whose compliance is verified periodically (in the case of SWIFT it is annually), depending on the type of service they provide. In case of recurring incidents, a special evaluation is performed.

\begin{tabular}{l|l}
\hline Assessment & Observed
\end{tabular}

Comments

The Manual of the SLBE should give clearer guidance on the expected behavior of participants in case of emergency situations. For instance, the procedures in case of a failure of the platform of a participant or the SLBE should be clearly established.

Although the BE undertakes regular testing of the contingency plan with the cooperation of system participants, it is recommended that the BE requires participants to put in place clear internal policies and procedures and to carry out operating audits. The BE should also periodically review the IT infrastructure of the participants to avoid operational risks.

The distance between the backup site and the main site should be assessed to ensure that it is sufficient to guarantee the continuity of the system in case of events such as natural disasters or terrorist acts. 


\section{Principle 8. The system should provide a means of making payments, which is practical for its users and efficient for the economy.}

Description

- The SLBE is an efficient channel for interbank payments and provides a means for the settlement of ancillary clearing systems with finality of payments. As long as there are enough funds in the account, the end-to-end processing time, from the moment a participant introduces an order to its final execution, is less than a second for national operations.

- The SLBE operates from 7:00 to 18:00. The queues are very small. The daily average of operations in queue is less than $0.5 \%$ of the transactions processed in the SLBE. The highest number is reached between 10a.m. and 12a.m. The average time in queue is about 35 minutes and no queues typically arise after 3 p.m.

- The system has appropriate functionalities such as access to intraday liquidity and optimization mechanisms which assure efficient management of queues and reduces the possibility of gridlock. All these features make the SLBE a very fluid system.

- There is a continuous bilateral optimization procedure for transactions before queuing and each time new funds arrive to the accounts, which reduces the necessity of large outstanding amounts of liquidity. A multilateral optimization mechanism is also available in case a gridlock occurs.

- There are interfaces between the RTGS accounts and the Public Debt management system which enhance the efficient management of liquidity.

- Participants use less than 50 percent of disposable intraday credit, which indicates there are no problems with liquidity availability.

- The Working Group on Payment Systems comprises the BE (in its capacity of manager of the SLBE) and the users of the SLBE. This group meets regularly to discuss issues such as customer's demands, trends in technology, and new products. After these discussions, the system may be updated depending on the results of a cost-benefit analysis.

- The system provides participants with additional services such as complete real-time information or permanent IT support. The system's flexibility has allowed the BE to introduce innovations to respond to participants' needs. Examples of this are the recent introduction of the liquidity reservation facility, the development of an algorithm to manage the queues, and new alternatives in communications.

- Pricing is based on a cost recovery policy. Sources of costs are analyzed separately, according to the Eurosystem methodology: operating, investment depreciation, capital costs and general costs. SLBE's fees have been lowered several times in recent years in response to improvements in cost recovery. The annual index of cost recovery for the years 2000 to 2004 was $89.3 \%, 101.9 \%, 111.1 \%, 100.6 \%$ and $99.6 \%$, respectively. Fees have been reduced since 2002. Fees differ according to the type of service. For instance, the fee for domestic interbank transfers is 0.50 euros, the fee for bilateral settlement through the SNCE is 0.25 euros. There is also a monthly charge of 500 euros. Fees are public and they are posted in the website on the BE.

- The system provides alternatives in communication (direct, SWIFT) in order to optimize participants' investment

- The system has enough capacity to cope with the current level of demand. It is permanently monitored so that, in case of an unexpected increase in the number of transactions, the BE is prepared to stop other processes, if necessary, to give priority to the SLBE.

- The SLBE provides all the services of a modern RTGS in an efficient way. Up to date, the $\mathrm{BE}$ has not received complaints from any of the participants. 


\begin{tabular}{|c|c|}
\hline Assessment & Observed. \\
\hline \multicolumn{2}{|l|}{ Comments } \\
\hline Principle 9. & $\begin{array}{l}\text { The system should have objective and publicly disclosed criteria for participation, } \\
\text { which permit fair and open access. }\end{array}$ \\
\hline Description & $\begin{array}{l}\text { - The main access criterion is being a supervised credit institution. Treasury departments of } \\
\text { public sector bodies, investment firms and organizations providing clearing or settlement } \\
\text { services subject to oversight by a competent authority, also have access to the SLBE. } \\
\text { - The access criteria and procedures are established by Circular } 5 / 1990 \text {, which has been } \\
\text { published in the Spanish Official Bulletin and the website of the BE. The rules are } \\
\text { disclosed to the general public. } \\
\text { - Participants may formalize their acceptance of the rules and operating procedures by } \\
\text { signing a contract upon joining the system. Admission to the system implies the opening } \\
\text { of a centralized account at the central bank. A legal opinion according to the terms of } \\
\text { reference given by the BE is also required for those institutions wishing to participate in } \\
\text { the SLBE. } \\
\text { - Institutions can choose to be direct or indirect participants in the SLBE. Indirect } \\
\text { participants have to sign a private arrangement with a direct participant. Indirect } \\
\text { participants do not have accounts at the BE, and thus cannot send orders directly to the } \\
\text { SLBE. Indirect participants' orders are introduced to the system by a direct participant, } \\
\text { who has an account at the BE. In this sense, direct participants control the orders of } \\
\text { indirect participants. There are no specific capital requirements to access the SLBE other } \\
\text { than those established to become an eligible institution. In July } 2005 \text { there were } 184 \\
\text { direct and } 36 \text { indirect participants. Most indirect participants are part of the group of the } \\
\text { direct one, so the financial risk is under control of the direct participant [?]. } \\
\text { - Access and exclusion criteria are identified in the Manual of the SLBE and are objective } \\
\text { and non discriminatory. Circular } 5 / 1990 \text { establishes that the BE can suspend or exclude a } \\
\text { participant, temporarily or indefinitely, when there is negligence or non-compliance with } \\
\text { the rules and regulations. } \\
\text { - Access to the SLBE is fair and open. }\end{array}$ \\
\hline Assessment & Observed. \\
\hline Comments & \\
\hline Principle 10. & $\begin{array}{l}\text { The system's governance arrangements should be effective, accountable and } \\
\text { transparent. }\end{array}$ \\
\hline Description & $\begin{array}{l}\text { - The SLBE is owned by the BE who is in charge of the elaboration and dissemination of } \\
\text { the rules and regulations of the system. The BE also manages and operates the SLBE. } \\
\text { - There is a Payment System Department which is under the supervision of the General } \\
\text { Director of Operations, Market and Payment Systems who reports to the Deputy } \\
\text { Governor. The Payment System Department has three divisions: the Settlement Systems } \\
\text { Analysis Division, the Centralized Payment Services Division, and the Credit Institutions } \\
\text { Payment Services Division. This organizational structure is published on the website of } \\
\text { the BE. } \\
\text { - The Payment System Department continuously monitors observance of all the CPSS CPs } \\
\text { by the SLBE. The Settlement Systems Analysis Division is responsible for the analysis }\end{array}$ \\
\hline
\end{tabular}




\begin{tabular}{|c|c|}
\hline & 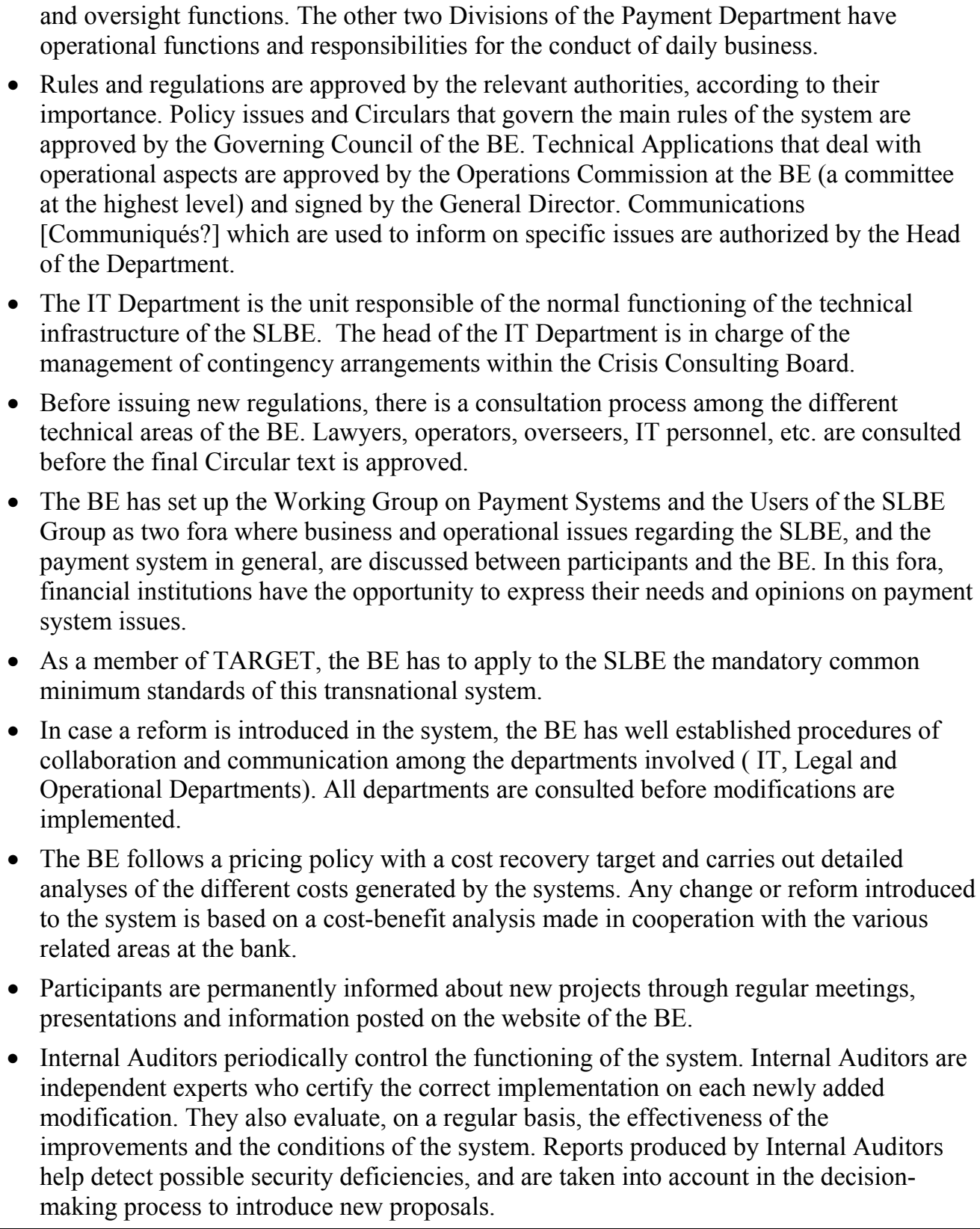 \\
\hline Assessment & Observed. \\
\hline \multicolumn{2}{|l|}{ Comments } \\
\hline Responsibility A. & $\begin{array}{l}\text { The central bank should define clearly its payment system objectives and should } \\
\text { disclose publicly its role and major policies with respect to systemically important } \\
\text { payment systems. }\end{array}$ \\
\hline Description & $\begin{array}{l}\text { - The role of the BE in the payments system is clearly defined in Law 13/1994 on the } \\
\text { Autonomy of the Banco de España, which establishes as one of its functions "to promote } \\
\text { the smooth functioning of payment systems". This law also entitles the central bank to } \\
\text { both regulate and operate clearing and settlement systems. The Autonomy Law also gives } \\
\text { the BE the oversight function of the payment systems and empowers it to obtain any }\end{array}$ \\
\hline
\end{tabular}




\begin{tabular}{|c|c|}
\hline & $\begin{array}{l}\text { - As explained in Principle 10, there is a Payment System Department which is under the } \\
\text { supervision of the General Director of Operations, Market and Payment Systems which } \\
\text { reports to the Deputy Governor. The Payment System Department has three divisions: the } \\
\text { Settlement Systems Analysis Division, the Centralized Payment Services Division and } \\
\text { the Credit Institution Payment Services Division. The Settlement Systems Analysis } \\
\text { Division is responsible for the analysis and oversight functions. The other two Divisions } \\
\text { of the Payment Department have operational functions and responsibilities for the } \\
\text { conduct of daily business. } \\
\text { - The BE also plays a catalyst role to promote the efficiency and safety of the system } \\
\text { through the discussions and coordination with financial institutions within the framework } \\
\text { of the working groups. } \\
\text { - The role, objectives, policies and general guidelines regarding payment systems are } \\
\text { disclosed and published by the BE on its website and through communications, press } \\
\text { notes and brochures. Periodic bulletins and articles are also used to make public the } \\
\text { policies and objectives of the payment system. For instance, the BE has recently } \\
\text { published on its website an article about its payment system oversight role: El Banco de } \\
\text { España y la vigilancia de los sistemas de pago. } \\
\text { - Regulation of the payment system is provided by circulars published by the BE in the } \\
\text { Official Gazette and on its website. }\end{array}$ \\
\hline Assessment & Observed. \\
\hline Comments & \\
\hline Responsibility B. & $\begin{array}{l}\text { The central bank should ensure that the systems it operates comply with the core } \\
\text { principles }\end{array}$ \\
\hline Description & $\begin{array}{l}\text { - The BE manages and operates the SLBE, continuously monitors the SLBE's observance } \\
\text { of the CPSS Core Principles, and carries out periodic self-assessment exercises. } \\
\text { - To monitor compliance with the core principles, the BE maintains and monitors statistical } \\
\text { data and operations. The organizational analysis unit of the payment system, the } \\
\text { Settlement Systems Analysis Division, is separate from the unit that operates the system. } \\
\text { - After the implementation of any change, an assessment of the compliance of the system } \\
\text { with the Core Principles is carried out. } \\
\text { - A review of the audit reports and analysis of incidents (such as temporary individual } \\
\text { problems of connectivity of a participant, gridlocks that make necessary the use of the } \\
\text { optimization mechanism, temporary energy supply failure, mistakes of participants, etc.) } \\
\text { are carried out to evaluate their impact on compliance with the Core Principles. }\end{array}$ \\
\hline Assessment & Observed. \\
\hline Comments & \\
\hline
\end{tabular}




\section{Responsibility C. The central bank should oversee observance with the core principles by the systems it does not operate and it should have the ability to carry out this oversight}

\begin{tabular}{|c|c|}
\hline Description & $\begin{array}{l}\text { - The same department that oversees the SLBE is also in charge of overseeing the other } \\
\text { systems not operated by the BE. } \\
\text { - Although currently there is not other privately operated systemically important payment } \\
\text { system, the BE oversees the observance of the core principles by systems operated by } \\
\text { other institutions, such as the SNCE, thus covering more than only the systemically } \\
\text { important payment systems. It also evaluated the recently dissolved net large payment } \\
\text { system Servicio Español de Pagos Interbancarios SPI. } \\
\text { - The main objective of the BE oversight function is to ensure the safety and efficiency of } \\
\text { payment systems. It promotes a sound legal basis, risk control mechanisms, automation } \\
\text { and modernization, balance between cooperation and competition, transparency and a } \\
\text { level playing field for access to the systems. } \\
\text { - Oversight is based on data analysis, the review of legal aspects of the self regulation of } \\
\text { the systems, the approval of norms, the analysis of payment instruments and new } \\
\text { developments, the assessment of international standards, the use of moral suasion, and } \\
\text { cooperation with participants, national and international bodies. } \\
\text { - The BE produces statistics and reports on the assessment of the systems vis à vis } \\
\text { international standards, reports on major incidents and reports on significant changes. }\end{array}$ \\
\hline Assessment & Non Applicable. \\
\hline Comments & $\begin{array}{l}\text { Although currently there is not other privately systemically important payment system, the } \\
\text { assessment of this principle shows the capacity and the ability of the BE to undertake the } \\
\text { oversight of any other system, as it was, in fact, demonstrated when there was another large } \\
\text { value payment system. However, statistics and reports on oversight activities should be } \\
\text { disseminated and published periodically. }\end{array}$ \\
\hline Responsibility I & $\begin{array}{l}\text { The central bank, in promoting payment system safety and efficiency through the core } \\
\text { principles, should cooperate with other central banks and with any other relevant } \\
\text { domestic or foreign authorities. }\end{array}$ \\
\hline
\end{tabular}

Description

- The BE has a close relationship with all the institutions involved in payment systems and continuously coordinates and cooperates with them. It has established working groups to discuss and to develop consensus on payment system issues.

- The BE has endorsed the Memorandum of Understanding on cooperation between banking supervisors and payment systems overseers, elaborated by the European System of Central Banks (ESCB).

- There is also collaboration with the Comisión Nacional del Mercado de Valores (CNMV, National Securities Market Commission) in charge of the supervision of the securities market, to coordinate issues related to the clearing and settlement of securities.

- In terms of international cooperation, BE representatives are members of the International Advisory Committee (IAC) under the Western Hemisphere Payments and Securities Initiative (WHI), whose Secretariat is in CEMLA (Centro de Estudios Monetarios Latinoamericanos). Thus, BE representatives participate in the activities of the Forum and assist CEMLA seminars and meetings regarding payments systems.

- The BE cooperates and coordinates with the rest of the central banks of the EU in the area of payment systems monitoring and oversight. This cooperation and coordination is also carried out with other Latin American central banks. 


\begin{tabular}{|l|l|}
\hline Assessment & Observed. \\
\hline Comments & \\
& \\
\hline
\end{tabular}

Table 5. Summary Observance of CPSS Core Principles and Bank Responsibilities in Applying the CPs-The SLBE

\begin{tabular}{|c|c|cc|}
\hline \multirow{2}{*}{ Assessment Grade } & \multicolumn{3}{|c|}{ Principles grouped by assessment grade } \\
\cline { 2 - 4 } & Count & List \\
\hline Observed & $10+4$ & CP 1,2,3,4,5,6,7,8,9,10 & Responsibilities A,B,C,D \\
\hline Broadly observed & 0 &.-- \\
\hline Partly observed & 0 &.-- \\
\hline Non-observed & 0 &.-- \\
\hline Not applicable & 0 &.-- \\
\hline
\end{tabular}

Table 6. Recommended Action Plan to Strengthen The SLBE

\begin{tabular}{|l|l|}
\hline \multicolumn{1}{|c|}{ Reference Principle } & \multicolumn{1}{|c|}{ Recommended Action } \\
\hline $\begin{array}{l}\text { Principle 1. The system should have a well-founded } \\
\text { legal basis under all relevant jurisdictions. }\end{array}$ & No recommendation. \\
\hline $\begin{array}{l}\text { Principle 2. The system's rules and procedures } \\
\text { should enable participants to have a clear } \\
\text { understanding of the system's impact on each of the } \\
\text { financial risks they incur through participation in it. }\end{array}$ & $\begin{array}{l}\text { The relevant rules and regulations of the system are } \\
\text { contained in a number of documents issued and modified } \\
\text { by the BE. Although the rules and regulations appear to } \\
\text { address all relevant aspects of the system, they are } \\
\text { contained in a number of circulars which are difficult to } \\
\text { follow. It is recommended that the organization of the } \\
\text { circulars of the BE are revised to improve readability and } \\
\text { transparency for participants. BE staff has indicated that } \\
\text { efforts in this direction are in progress. }\end{array}$ \\
\hline $\begin{array}{l}\text { Principle 3. The system should have clearly defined } \\
\text { procedures for the management of credit risks and } \\
\text { liquidity risks, which specify the respective } \\
\text { responsibilities of the system operator and the } \\
\text { participants and which provide appropriate } \\
\text { incentives to manage and contain those risks. }\end{array}$ & $\begin{array}{l}\text { Although the liquidity reservation facility is useful for } \\
\text { participants, the BE should monitor the use of this } \\
\text { facility to avoid possible discrimination against certain } \\
\text { payments that may have to wait until the end of the day } \\
\text { to be settled. The BE should also make sure that use of } \\
\text { the liquidity reservation facility does not unduly prevent } \\
\text { the debiting of accounts during the day. }\end{array}$ \\
\hline $\begin{array}{l}\text { Principle 4. The system should provide prompt final } \\
\text { settlement on the day of value, preferably during the } \\
\text { day and at a minimum at the end of the day. }\end{array}$ & \begin{tabular}{l} 
No recommendation. \\
\hline
\end{tabular}
\end{tabular}

5 All CPSS principles were rated as observed. The recommended actions are relatively minor measures that could be taken to make the SLBE even more robust. 
\begin{tabular}{|l|l|}
\hline Principle 5. A system in which multilateral netting & Not applicable.
\end{tabular}

takes place should, at a minimum, be capable of

ensuring the timely completion of daily settlements

in the event of an inability to settle by the participant

with the largest single settlement obligation.

\begin{tabular}{|l|l|l}
\hline Principle 6. Assets used for settlement should & No recommendation.
\end{tabular}

preferably be a claim on the central bank; where

other assets are used, they should carry little or no

credit risk and little or no liquidity risk.

Principle 7. The system should ensure a high degree

of security and operational reliability and should

have contingency arrangements for timely

completion of daily processing.

Principle 8 . The system should provide a means of

making payments, which is practical for its users and efficient for the economy.

Principle 9. The system should have objective and

publicly disclosed criteria for participation, which

permit fair and open access.

Principle 10. The system's governance arrangements

should be effective, accountable and transparent.

Responsibility A. The central bank should define

clearly its payment system objectives and should

disclose publicly its role and major policies with

respect to systemically important payment systems.

Responsibility B. The central bank should ensure

that the systems it operates comply with the core

principles.

Responsibility C. The central bank should oversee observance with the core principles by systems it

does not operate and it should have the ability to

carry out this oversight.

Responsibility D. The central bank, in promoting

payment system safety and efficiency through the

core principles, should cooperate with other central

banks and with any other relevant domestic or

foreign authorities.

The Manual of the SLBE should be revised to give clearer guidance on the expected behavior of the participants in case of emergency situations. For instance, the procedures in case of failure of the platform of a participant or the SLBE should be clearly established.

Although the BE undertakes regular testing of the contingency plan with the cooperation of system participants, it is recommended that the $\mathrm{BE}$ require participants to put in place clear internal policies and procedures and to carry out operating audits. A periodic review of the IT infrastructure of the participants to avoid operational risks is recommended.

The distance between the backup site and the main site should be assessed to ensure that it is sufficient to guarantee the continuity of the system in case of events such as natural disasters or terrorist acts.

No recommendation.

No recommendation.

No recommendation.

No recommendation.

No recommendation.

Statistics and reports on oversight activities should be disseminated and published periodically.

No recommendation. 


\section{Authorities' response to the assessment}

49. The authorities thank the IMF team and the assessor for all the work undertaken and welcome its assessment, with which it is in broad agreement. The minor shortcomings pointed out in the assessment, that do not prevent the full observance of the Core Principles, have been addressed by the authorities and appropriate measures are being implemented to tackle the issue in the first half of 2006. Given Banco de España's membership to the Eurosystem, some issues mainly to improve the payment system's business continuity, are being tackled collectively. 